\title{
ANALISIS PENGARUH KOMUNIKASI TERAUPETIK PERAWAT TERHADAP KEPUASAN KELUARGA PASIEN SKIZOFRENIA DI RUMAH SAKIT JIWA
}

\author{
Maria Haryanti Butarbutar ${ }^{1}$, Muflih $^{2}$, Naomi Isabella Hutabarat ${ }^{3}$ \\ 1\&2, Program Studi D3 Keperawatan Institut Kesehatan Helvetia Medan \\ 3, Prodi D3 Kebidanan Poltekkes Tarutung \\ *Email : maria_haryanthi@yahoo.com.au
}

\begin{abstract}
Abstrak
Data WHO 2016 terdapat 35 juta orang terkena depresi, 60 juta orang terkena bipolar, Prevalensi gangguan jiwa berat seperti skizofrenia mencapai 400 orang atau sebanyak 1,7 per 1.000 penduduk sehingga peneliti tertarik untuk menganalisis pengaruh komunikasi terapeutik perawat terhadap kepuasan keluarga pasien skizofrenia di rumah sakit jiwa Prof. Muhammad Ildrem Medan 2019. Tujuan penelitian ini adalah menganalisis pengaruh komunikasi terapeutik perawat terhadap kepuasan keluarga pasien skizofrenia di rumah sakit jiwa Prof. Muhammad Ildrem Medan. Metode penelitian menggunakan desain penelitian deskriptif. Populasinya adalah keluarga pasien skizofrenia di rumah sakit jiwa Prof. M. Ildrem Medan dengan sampel sebanyak 150 orang dengan tehnik cross secsional total sampling. Pengumpulan data dilakukan dengan cara wawancara dan pembagian kuesioner. Hasil penelitian fase pra interaksi pvalue $=$ $0.010 \leq 0.05$, tahap orientasi pvalue $=0.004 \leq 0.05$, tahap kerja pvalue $=0.000 \leq 0.05$, dan tahap terminasi pvalue $=0.005 \leq 0.05$ yang artinya ada hubungan antara komunikasi teraupetik dengan kepuasan keluarga pasien skizofrenia. Untuk hasil multivariatnya semua tahap komunikasi menpungaruhi kecuali tahap orientasi dengan kepuasan keluarga pasien skizoofrenia. Saran agar perawat dapat melakukan komunikasi teraupetiknya dalam memberikan pelayanan kesehatan kepada pasien dan keluarga pasien guna kesembuhan, kenyamanan dan kesehatan pasien. Perawat harus mengerti tentang tehnik komunikasi teraupetik dan tahap tahap dalam berkomunikasi untuk menjalin kepercayaan antara perawat dan pasien serta keluarga pasien.
\end{abstract}

Kata Kunci : kepuasan, skizofrenia, keluarga pasien, perawat, komunikasi teraupetik

\begin{abstract}
Analysis Of The Effect Of Nurse Communication Therapeutic Towards Satisfaction In The Family Of Schizophrenia Patients In Psychiatric Hospital. WHO data in 2016 there are 35 million people affected by depression, 60 million people affected by bipolar disorder, the prevalence of severe mental disorders such as schizophrenia reaches 400 people or as many as 1.7 per 1,000 population so researchers are interested in analyzing the influence of nurses' therapeutic communication on the family satisfaction of schizophrenic patients in hospitals the soul of Prof. Muhammad Ildrem Medan 2019. The purpose of this study was to analyze the effect of nurses' therapeutic communication on the family satisfaction of schizophrenic patients in Prof. psychiatric hospitals. Muhammad Ildrem Medan. The research method uses descriptive research design. The population is the family of schizophrenia patients in Prof. mental hospital M. Ildrem Medan with a sample of 150 people with a total sampling cross-sectional technique. Data collection was carried out by interview and questionnaire distribution. The results of the pre-interaction phase of the study of $p$-value $=0.010 \leq 0.05$, the orientation phase of $p$-value $=0.004 \leq 0.05$, the work phase $p$-value $=0.000 \leq 0.05$, and the termination stage $p$-value $=0.005 \leq 0.05$ which means there is a relationship between therapeutic communication with family satisfaction of schizophrenia patients. For multivariate results, all communication stages affect except the orientation phase with the family satisfaction of schizophrenia patients. Suggestions that nurses can communicate therapeutic in providing health services to patients and patients' families for healing, comfort, and health of patients. Nurses must understand about therapeutic communication techniques and stages in communication to establish trust between nurses and patients and the patient's family.
\end{abstract}

Keywords: satisfaction, schizophrenic, patient families, nurse, communication therapeutic 


\section{Pendahuluan}

Pelayanan kesehatan terhadap masyarakat dikembangkan sejalan dengan tanggung jawab pemerintah melindungi rakyat Indonesia dari berbagai masalah kesehatan yang berkembang. Kesahatan adalah hak asazi manusia yang tercantum dalam Undang Undang Dasar tahun 1945 (Kemenkes, 2015).

Kepuasan pasien adalah suatu tingkat perasaan pasien yang timbul sebagai akibat dari kinerja layanan kesehatan yang diperolehnya setelah pasien membandingkannya dengan apa yang diharapkannya, fungsi komunikasi terapeutik adalah untuk mendorong dan menganjurkan kerjasama antara perawat-klien melalui hubungan perawat-klien. Perawat berusaha mengungkapkan perasaan, mengidentifikasi dan mengkaji masalah serta mengevaluasi tindakan yang dilakukan dalam perawatan. mengungkapkan bahwa seorang perawat profesional selalu mengupayakan untuk berperilaku terapeutik, yang berarti bahwa tiap interaksi yang dilakukan menimbulkan dampak terapeutik yang memungkinkan klien untuk tumbuh dan berkembang. Tujuan hubungan terapeutik diarahkan pada petumbuhan klien (Muhith, 2015).

Data WHO pada tahun 2012 menyatakan skizofrenia merupakan gangguan mental berat yang mempengaruhi sekitar 7 per seribu dari populasi orang dewasa, terutama di kelompok usia 15-35 tahun. Meskipun insiden rendah (3-10.000), prevalensi yang tinggi terjadi karena kronisitas (Khairunisa, 2016).

Data Riset Kesehatan Dasar (Riskesdas) 2013 mencatat prevalensi gangguan jiwa berat di Indonesia mencapai 1,7 per mil, artinya 1-2 orang dari 1.000 penduduk di Indonesia mengalami gangguan jiwa berat. Fenomena gangguan jiwa pada saat ini mengalami peningkatan yang sangat signifikan, dan setiap tahun di berbagai belahan dunia jumlah penderita gangguan jiwa terus bertambah. Data Riskesdas 2013 menyebutkan jumlah seluruh rumah tangga yang dianalisis gangguan jiwa adalah 294.959 terdiri dari 1.027.763 anggota rumah tangga yang berasal dari semua umur. Rumah tangga yang menjawab memiliki anggota rumah tangga dengan gangguan jiwa berat sebanyak 1.655 , terdiri dari 1.588 rumah tangga dengan 1 orang anggota rumah tangga, 62 rumah tangga memiliki 2 orang anggota rumah tangga, 
4 rumah tangga memiliki 3 anggota rumah tangga dan 1 rumah tangga memiliki 4 orang anggota rumah tangga yang mengalami gangguan jiwa berat. Jumlah seluruh responden dengan gangguan jiwa berat berdasarkan data Riskesdas 2013 adalah sebanyak 1.728 orang (Permenkes, 2016).

Data WHO 2016 terdapat 35 juta orang terkena depresi, 60 juta orang terkena bipolar, 21juta terkena skizofrenia, serta 47,5 juta terkena demensia. Di indonesia terjadi berbagai faktor biologis, psikologis dan sosial dengan keanekaragaman penduduk, jumlah gangguan jiwa terus bertambah yang berdampak pada penambahan beban negara dan penurunan produktivitas manusia untuk jangka panjang (Permenkes, 2016).

Menurut (Tjiptono, 2012) kepuasan pelanggan merupakan respon pelanggan terhadap evaluasi persepsi atas perbedaan antara harapan awal sebagaimana dipersepsikan setelah memakai atau mengkonsumsi produk bersangkutan. Kepuasan pelanggan bukanlah konsep absolut, melainkan relatif atau tergantung pada apa yang diharapkan pelanggan. Operasionalisasi pengukuran kepuasan pelanggan bisa menggunakan sejumlah faktor, seperti ekspektasi, tingkat kepentingan (importance), kinerja, dan faktor ideal (Tjiptono, 2012).

Kepuasan dalam kamus besar Bahasa Indonesia adalah perihal atau perasaan puas, kesenangan, kelegaan. Kepuasan juga berarti tingkat perasaan seseorang setelah membandingkan kinerja atau hasil yang dirasakan dibandingkan dengan harapannya. Kepuasan manusia merupakan sesuatu yang subyektif dan dinamis. Bagi manusia kepuasan itu bersifat sementara, jika suatu kebutuhan telah terpuaskan maka kebutuhan lain akan muncul menuntut kepuasan (Kurnia \& Damayanti, 2011)

Di Indonesia terdapat 6-19 orang per 1000 penduduk dunia mengalami skizofrenia. Hasil survey di Indonesia memperlihatkan bahwa sekitar 1-2\% penduduk menderita skizofrenia, hal ini berarti sekitar 2-4 juta jiwa dari jumlah tersebut diperkirakan penderita yang aktif sekitar 7 ratus ribu sampai 1,4 juta jiwa. Penderita yang dirawat di bagian psikiatri di Indonesia hampir 70\% karena skizofrenia (Prastyo, 2015)

Jumlah gangguan jiwa di Sumatera Utara mengalami peningkatan. Berdasarkan Dinas Kesehatan, tercatat November 2012 terdapat sebanyak 1.157 orang yang mengalami penyakit depresi berat bahkan meningkat signifikan 
hanya dalam kurun waktu satu bulan dan diperhitungkan hingga Desember 2017. (Utara, 2015) Berkomunikasi dengan penderita gangguan jiwa membutuhkan sebuah tehnik khusus, berkomunikasi dengan orang gangguan jiwa berbeda dengan gangguan akibat gangguan penyakit fisik. Komunikasi dengan penderita gangguan jiwa membutuhkan sebuah dasar pengetahuan tentang ilmu komunikasi yang benar, ide yang mereka lantarkan terkadang melompat (Muhith, 2015).

Kepuasan menjadi aset yang sangat berharga apabila pasien merasa maka mereka akan terus melakukan pemakaian jasa, tetapi jika mereka merasa tidak puas akan memberitahukan dua kali lebih hebat kepada orang lain tentang pengalaman buruknya (Muhith, 2015).

Komunikasi terapeutik adalah membantu pasien untuk memperjelas dan mengurangi beban perasaan dan pikiran serta dapat mengambil tindakan yang efektif untuk pasien, membantu mempengaruhi orang lain, lingkungan fisik dan diri sendiri (Muhith, 2015).

Tujuan penelitian ini adalah menganalisis pengaruh komunikasi terapeutik perawat terhadap kepuasan keluarga pasien skizofrenia di rumah sakit jiwa Prof. Muhammad Ildrem Medan.

\section{Metode}

Penelitian ini merupakan penelitian kuantitatif dengan metode analitik dengan desain studi cross sectional (potong lintang). Besar sampel dalam penelitian ini adalah sebanyak 150 orang keluarga pasien. Analisa Data dilakukan dengan tehnik analisis univariat untuk mendapatkan gambaran setiap variable dan analisis multivariate dilakukan untuk mengetahui analisis resiko antara variable bebas (independen) dengan variable terikat (dependen) menggunakan uji statistic regresi linier pada tingkat kemaknaan 95\%. Menganalisis pengaruh komunikasi terapeutik perawat terhadap kepuasan keluarga pasien skizofrenia di rumah sakit jiwa Prof. Muhammad Ildrem Medan.

Populasi dalam penelitian ini adalah semua keluarga pasien yang skizofrenia di RSJ Prof. Mohammad Ildrem Medan sebanyak 150 orang keluarga pasien dan pengambilan sampel dengan menggunakan accidental sampling (Notoatmodjo, 2010). Penelitian dilakukan pada bulan Oktober 2018 sampai selesai. 
Butarbutar, Maria Haryanti dkk. Analisis Pengaruh Komunikasi Teraupetik Perawat Terhadap Kepuasan Keluarga Pasien Skizofrenia Di Rumah Sakit Jiwa. Journal of Borneo Holistic Health, Vol.3, No. 1 Juni 2020 hal 11-19

\section{Hasil}

Penelitian ini dilaksanakan di lingkungan Rumah Sakit Jiwa Prof. M. Ildrem Medan. Pengumpulan data dimulai dari bulan Juli 2018 sampai bulan Oktober 2018. Sampel pada penelitian ini adalah keluarga pasien skizofrenia rawat jalan. Penelitian ini telah disetujui oleh Komisi Etik no:582. pengumpulan data pada penelitian ini dilakukan secara primer dimana peneliti melakukan wawancara langsung kepada para responden dengan menggunakan kuesioner, sebelum dilakukan wawancara, status pasien diperiksa terlebih dahulu untuk mengetahui dan memastikan apakah responden tersebut telah didiagnosa skizofrenia dan sesuai kriteria inklusi dan ekslusi. Setelah dilakukan pengolahan data, maka hasil penelitian dapat disajikan dan dianalisis secara univariat dengan tabel distribusi frekuensi serta analisis bivariat dengan uji chi-square yang disertai dengan narasi sebagai berikut :

\begin{tabular}{|c|c|c|}
\hline $\begin{array}{l}\text { Tabel.1 } \\
\text { berdasarkan } \\
\text { pendidikan, } \\
\text { pembayaran }\end{array}$ & $\begin{array}{l}\text { Karakteristik } \\
\text { umur, jenis } \\
\text { pekerjaan, } \\
\text {, alamat }\end{array}$ & $\begin{array}{c}\text { responden } \\
\text { kelamin, } \\
\text { rawatan, }\end{array}$ \\
\hline Kategori & Frekuensi & $\%$ \\
\hline $26-35$ & 30 & 20.0 \\
\hline $36-45$ & 70 & 46.7 \\
\hline $46-55$ & 39 & 26.0 \\
\hline $56-65$ & 4 & 2.7 \\
\hline$>65$ & 7 & 4.7 \\
\hline laki-laki & 53 & 35.3 \\
\hline perempuan & 97 & 64.7 \\
\hline
\end{tabular}

\begin{tabular}{ccc}
\hline SD & 18 & 12.0 \\
SMP & 46 & 30.7 \\
SMA & 31 & 20.7 \\
PT & 55 & 36.7 \\
\hline PNS & 26 & 17.3 \\
\hline Umum & 56 & 37.3 \\
BPJS & 94 & 62.7 \\
\hline kelas 1 & 23 & 15.3 \\
kelas 2 & 54 & 36.0 \\
kelas 3 & 73 & 48.7 \\
\hline P. Swasta & 25 & 16.7 \\
Wiraswasta & 49 & 32.7 \\
Petani & 7 & 4.7 \\
Buruh & 19 & 12.7 \\
Tidak Bekerja & 24 & 16.0 \\
\hline Medan & 54 & 36.0 \\
Luar Medan & 96 & 64.0 \\
\hline
\end{tabular}

Berdasarkan karakteristik

responden menurut pembayaran menunjukkan BPJS sebanyak 94 orang (62.7\%), umum sebanyak 56 orang (37.3\%). Berdasarkan kelas rawatan bahwa kelas 1 ada sebanyak 23 orang (15.3), kelas II sebanyak 54 orang (36\%), kelas III sebanyak 73 orang $(48.7 \%)$, berdasarkan umur bahwa umur 26- 35 tahun sebanyak 30 orang (20\%), 36-45 sebanyak 70 orang (46.7\%), 46-55 sebanyak 39 orang (26\%), 56-65 sebanyak 4 orang $(2.7 \%)$ dan $>65$ sebanyak 7 orang $(4.7 \%)$. Berdasarkan jenis kelamin laki-laki sebanyak 53 orang (35.3\%) dan perempuaan 97 orang (64.7\%). Berdasarkan pendidikan bahwa SD sebanyak 18 orang (12\%), SMP, 46 orang (30.7\%), SMA sebanyak 31 orang (20.7\%) dan PT sebanyak 55 orang (36.7\%). Berdasarkan pekerjaan bahwa PNS sebanyak 26 orang (17.3\%), P. 
Swasta sebanyak 25 orang $(16.7 \%)$, wiraswasta sebanyak 49 orang (32.7\%), petani sebanyak 7 orang (4.7\%), buruh sebanyak 19 orang $(12.7 \%)$ dan tidak bekerja sebanyak 24 orang (16\%). Berdasarkan alamat bahwa di Medan sebanyak 54 orang (36\%) dan berada di luar medan sebanyak 96 orang $(64 \%)$.

Tabel. 2 Karakteristik responden berdasarkan komunikasi teraupetik

\begin{tabular}{ccc}
\hline Pra interaksi & Frekuesi & \% \\
\hline Kurang & 50 & 33.3 \\
Baik & 100 & 66.7 \\
\hline Orientasi & Frekuesi & \% \\
\hline Kurang & 80 & 53.3 \\
Baik & 70 & 46.6 \\
\hline Tahap kerja & Frekuesi & \% \\
\hline Kurang & 32 & 21.3 \\
Baik & 118 & 78.7 \\
\hline Tahap Terminasi & Frekuesi & $\mathbf{\%}$ \\
\hline Kurang & 33 & 22 \\
Baik & 117 & 78 \\
\hline
\end{tabular}

Berdasarkan karakteristik responden komunikasi teraupetik bahwa pra interaksi kurang sebanyak 50 orang (33.3\%) dan baik sebanyak 100 orang $(66.7 \%)$. Berdasarkan orientasi kurang sebanyak 80 orang $(53.3 \%)$ dan baik sebanyak 70 orang (46.6\%), berdasarkan tahap kerja kurang sebanyak 32 orang (21.3\%) dan baik sebanyak 118 orang (78.7\%) dan tahap terminasi kurang sebanyak 33 orang (22\%) dan baik sebanyak 117 orang (78\%).
Tabel 3. Kepuasan keluarga pasien skizofrenia

\begin{tabular}{ccc}
\hline Kepuasan & Frekuesi & $\%$ \\
\hline Puas & 132 & 88 \\
Kurang puas & 18 & 12 \\
\hline
\end{tabular}

Berdasarkan

karakteristik

kepuasan keluarga pasien skizofrenia bahwa yang merasa puas sebanyak 132 orang $(88 \%)$ dan kurang puas sebanyak 18 orang $(12 \%)$.

\section{Pembahasan}

Mayoritas responden berdasarkan pembayaran secara asuransi BPJS sebanyak 94 orang (62.7\%), berdasakan kelar rawatan sebanyak 73 orang (48.7\%), berdasarkan usia 36-45 tahun sebanyak 70 orang (46.7\%). Berdasarkan jenis kelamin yaitu perempuan sebanyak 97 orang (64.7\%). Berdasarkan pendidikan yaitu PT sebanyak 55 orang (36.7\%). Berdasarkan pekerjaan mayoritas yaitu wiraswasta sebanyak 49 orang (32.7\%), dan yang mayoritas yang berdomisili adalah diluar medan sebanyak 96 orang $(64 \%)$.

Berdasarkan komunikasi teraupetik bahwa yang dominan dalam pra interaksi sebanyak 100 orang (66.7\%), orientasi kurang sebanyak 80 orang (53.3\%), tahap kerja yaitu baik sebanyak 118 orang (78.7\%), tahap terminasi baik sebanyak 117 orang 
(78\%) dan berdasarkan kepuasan bahwa mayoritas adalah keluarga pasien merasa puas akan komunikasi teraupetik perawat sebanyak 132 orang $(88 \%)$.

Berdasarkan analisis bivariat bahwa fase pra interaksi pvalue $=0.010$ $\leq 0.05$, yang artinya bahwa ada hubungan antara fase pra interaksi dengan kepuasan pasien. tahap orientasi pvalue $=0.004$ yang artinya ada hubungan antara tahap orientasi komunikasi teraupetik dengan kepuasan keluarga pasien $\leq 0.05$. tahap kerja pvalue $=$ $0.000 \leq 0.05$ yang artinya ada hubungan antara komunikasi teraupetik perawat dengan kepuasan keluarga pasien, dan tahap terminasi pvalue $=0.005 \leq 0.05$ yang artinya ada hubungan antara komunikasi teraupetik keperawatan dengan kepuasan keluarga pasien. semua tahap dalam komunikasi berhubungan dengan kepuasan keluarga pasien $(\leq 0.05)$.

Dari hasil penelitian ini bahwa keluarga pasien merasakan kepuasan atas komunikasi teraupetik yang dilakukan oleh perawat, namun perlu diberikan soluasi bagi perawat yang belum dapat melakukan komunikasi teraupetik saat berinteraksi kepada pasien dan keluarga pasien untuk menerapkan terapi dan komunikasi yang lebih efektif saat berhubungan melakukan tindakan atau asuhan kepada pasien dan keluarga pasien karena komunikasi teraupetik akan mempengaruhi pelayanan yang prima yang diterima oleh pasien dan keluarga pasien saat mereka berada dilingkungan rumah sakit jiwa pusat Prof. Muhammad Ildrem Medan.

Dalam analisi uji multivariat didapatkan hasil hanya tahap orientasi dengan hasil B 0.210 yang tidak berpengaruh terhadap kepuasan keluarga pasien skizofrenia di rumah sakit Prof. Muhammad Ildrem Medan.

Dalam hasil penelitian ini menyatakan bahwa perawat melakukan komunikasi secara teraupetik terhadap pasien dan keluarga pasien merasakan adanya perubahan kesembuhan kepada pasien dari tindakan dan teraupetik yang diberikan perawat tersebut namun masih ada perawat yang hanya melakukan tindakan atau terapi tanpa memperkenalkan diri terlebih dahulu, seperti nama dan panggilannya kesukaan pasien dan tidak menjelaskan kontrak waktu seperti memperjelas tujuan tindakan dan kegiatan yang diberikan dan waktu yang telah disepakai oleh pasien dan keluarga pasien terlebih dahulu. Apalagi pada saat keluarga pasien mengambil obat dari rumah mereka yang jauh dari kota Medan. Sehingga antara perawat dan pasien serta keluarga pasien tidak terjadi hubungan 
yang saling percaya dan ketidakmampuan perawat membangun dan memelihara hubungan antara pihak perawat dan pasien atau keluarga pasien sehingga menimbulkan masalah seperti pasien dan keluarga pasien merasa tidak dipedulikan karena tempat tinggal yang jauh dari kota Medan (diluar kota Medan) sehingga tingkah laku orang di kota Medan berbeda dengan diluar kota Medan sehingga tingkah laku dan kebiasaan serta cara bicara pasien dan keluarga pasien berbeda dengan di kota Medan sehingga sulit untuk dipahami (Riyadi \& Yuniarti, 2016) Untuk tahap komunikasi pra interaksi, tahap kerja dan tahap terminasi dinyatakan lebih berpengaruh terhadap kepuasan pasien dimana perawat melaksanakan kegiatan yang telah melakukan terapi terlebih dahulu direncanakan dalam asuhan kepeawatan sehingga perawat dapat menolong pasien dalam mengatasi masalah masalah kesehatan yang dialaminya dan perkembangan kesehatan pasien dapat dilihat dan dirasakan oleh keluarga pasien yang skizofrenia untuk meningkatkan kemandiriannya dan tidak ada penolakan ataupun menarik diri dan perawat melakukannya berdasarkan kompetensi dan tanggung jawabnya sebagai perawat terhadap kesembuhan pasien yang skizofrenia (Muhith, 2015).

Maka perawat dalam memberikan pelayanan harus senantiasa menggunakan kiat-kiat keperawatan yang salah satunya adalah nursing is laughing dan memperkenalkan diri deng berarti perawat meyakini bahwa senyum dan menyebutkan perkenalkan merupakan suatu kiat dalam memberikan pelayanan keperawatan kepada pasien untuk meningkatkan rasa nyaman pasien dan kepercayaan dan membentuk suatu atmosfir saling percaya antara perawat, pasien skizofrenia dan keluarga pasien.

\section{Kesimpulan}

Berdasarkan hasil dari penelitian diatas bahwa terapi yang diberikan perawat harus terlebih dahulu berdasarkan komunikasi yang disebut dengan komunikasi teraupetik yang mempunyai beberapa tahap. Seluruh tahap yang ada dalam komunikasi tersebut haruslah dilakukan secara holistik dan berurutan guna menjalin hubungan yang baik kepada pasien dan keluarga pasien serta memberikan rasa percaya dan kemanyamanan walaupun jauh pasien dan keluarga pasien jauh diluar kota. Perawat sebelum melakukan tindakan harus menyebutkan dan 
memperkenalkan diri lebih dahulu dan mengetahui juga nama serta panggilan nama dari pasien untuk membentuk suatu ikatan dan hubungan terrsebut antara perawat dengan pasien. Komunikasi dapat memberi kesembuhan kepada pasien dan bukan hanya dari obat obatan saja namun dari hubungan yang baik antara perawat dengan pasien yang memberi kenyamanan terhadap pasien dan keluarga pasien.

Pasien dan keluarga pasien akan merasakan kepuasan apabila pasien dan keluarga pasien sudah mendapatkan pelayanan kesehatan yang baik yang diberikan oleh perawat yang bertugas di rumah sakit jiwa pusat Prof. Muhammad Ildrem Medan baik yang bersifat fisik, kenyamanan dan keamanan serta komunikasi teraupetik yang baik.

\section{Referensi}

Kemenkes, R. I. (2015). Profil Kesehatan Indonesia 2015. Jakarta: Kementerian Kesehatan Republik Indonesia.

Khairunisa, D. (2016). Hubungan Pengetahuan Keluarga Dengan Kepatuhan Minum Obat Pasien Skizofrenia Rawat Jalan Di Rumah Sakit Jiwa Prof. M. Ildrem Medan (Doctoral dissertation).

Kurnia, E., \& Damayanti, N. A. (2011). Formula Penghitungan Tenaga
Keperawatan Modifikasi FTE dengan Model Asuhan Keperawatan Profesional Tim. Jurnal Ners, 6(1), 11-20.

Muhith, A. (2015). Pendidikan keperawatan jiwa: Teori dan aplikasi. Penerbit Andi.

Notoatmodjo, S. (2010). Metododologi Penelitian Kesehatan.

Prastyo, A. (2015). HUBUNGAN PENGETAHUAN KELUARGA TENTANG GANGGUAN JIWA DAN DUKUNGAN KELUARGA DENGAN KEPATUHAN MINUM OBAT PASIEN SKIZOFRENIA DI WILAYAH PUSKESMAS GAMPING I SLEMAN YOGYAKARTA (Doctoral dissertation, STIKES Jenderal Achmad Yani Yogyakarta).

Permenkes, R. I. (2016). Peraturan Menteri Kesehatan Republik Indonesia Nomor 31 Tahun 2016 tentang Perubahan Atas Peraturan Menteri Kesehatan Nomor 889/Menkes/Per/V/2011 tentang Registrasi, Izin Praktik, Dan Izin Kerja Tenaga Kefarmasian.

Riyadi, s., \& Yuniarti, y. (2016). Hubungan motivasi kerja dan lama kerja perawat dengan penerapan komunikasi terapeutik pada klien di rumah sakit pku muhammadiyah kotagede yogyakarta. Jurnal kesehatan karya husada, 4 (1).

Tjiptono, F. (2012). Service Management: Mewujudkan layanan prima edisi II. Yogyakarta: Andi 